\title{
THE AGRICULTURAL SIGNIFICANCE OF THE STUDY OF NEW ZEALAND BLUEGRASS AGROPYRON SCABRUM
}

\author{
By H. E. Connor \\ Botanist, Botany Division, Department of Scientific \\ and Industrial Research.
}

This paper will chiefly concern itself with a discussion of what are generally referred to as the low tussock grasslands of the high country, called by Cockayne the montane tussock grasslands. I wish to make it clear that I am not concerning myself with those areas of tussoek which can be brought in under the plough and which are usually known as lowland low tussock grassland.

It has been stated frequently that the natural grasslands of New Zealand developed in the absence of a grazing animal, which is true if one excludes moas; and this following statement is held as a corollary: the tussock grasslands as a consequence are not capable of withstanding the demands made of them in grassland farming. The herbivorous grazing animal as part of the environment in adapting natural grassland to grazing is a necessity. In North America, for example, the bison and other herd animals assisted in the development of the prairies which are now so suited to the beef cattle era. The tall and short grass prairies, however, were brought into a balance with the migratory bison populations and stabilised for grazing.

The tussock grasslands of New Zealand were not subjected to a balanced environmental pressure by the sheep which were grazed through Otago and Canterbury. To say that the native grasslands have received a fair trial and have been found guilty of failing to withstand grazing contravenes even the first principles of scientific method. They were not given a fair trial.

The tussock-grasslands of New Zealand were in the sixties and seventies grossly overstocked, severely 
burned to promote new edible growth, and then burned again and again till the tussocks were no longer capable of recovery. The consequent depletion in cover, the invasion of rabbits, and the eventual and in some areas almost complete loss of vegetation bring up to date the history of the native tussock grasslands. All this is used as evidence to prove that the native grasses cannot stand up to the demands made on them by grazing animals.

Do not for one moment think that those natural grasslands which were fortunate enough to develop in the presence of a grazing animal have miraculously escaped unscathed. The seemingly endless plains of North America have also succumbed to the ravages of overstocking. Large-scale ranching has depauperated the American prairie.

We see the same results in both sets of conditioned evolution (i.e., both with and without the grazing animal). The problem now confronting both is one of grassland renovation. Two immediate channels of investigation are open. The first and the most widely tried method of rehabilitation is that of plant introduction. This is simply the importation of forage plants which are known to do well in other countries where the grazing animal has been associated with grassland development, and to detect from trials made on these species those most suitable. The second approach to the problem is to search thoroughly those grass, pasture, and browse species which are present in native grassland.

The native grasslands of New Zealand have evolved under conditions peculiar to them. To match New Zealand tussock grassland conditions with some part of the prairies or the steppes or the pampas so that suitable plants could be imported and expected to succeed would be a work of such magnitude as to be well-nigh impossible. There are too many variables. The plant must be suited edaphically, climatologically, and ecologically.

The haphazard introduction of a species which meets with temporary favour in another country, where it is soon to be superseded by some other flyby-night, is not going to solve the renovation problem. Of course, it would be foolhardy to adopt the indifferent attitude that perhaps some little good will come of plant introduction schemes.

How are renovation problems being approached in other countries with depleted areas of native grass- 
land? All self-respecting countries have their plant introduction services, all have the equivalent of the Soil Conservation Service, but, to my mind the most important, all have research groups whose work is concentrated on the evaluation of species native to their countries, provinces, or states. These researches into native species appear to have held a secondary position till more recently, for "The glamour of introductions has diverted much deserved attention away from native species."

In an effort to parallel the trials which are now being made on imported species and in an endeavour to find a type of plant equal or superior to those importations a full-scale study was begun in 1947 on New Zealand bluegrass Ayropyron scabrum. Why choose New Zealand bluegrass and how is the study being made are the two questions which I now propose to answer. In reply to my first question: New Zealand bluegrass was chosen for a number of reasons. Buchanan was the first botanist to comment on the suitability of New Zealand bluegrass. He remarked that the early settlers considered it a good grass for horses and cattle and that the settlers knew it as "blue tussac grass" or "blue oat grass." Armstrong, calling it by the name of blue wheat grass, said of it that it was one of "the best native grasses for general farm purposes" and "which fully deserve[d] a trial from all farmers anxious to improve the productiveness of their pastures." By 1912 Petrie had said that it was "a species of high economic value in spite of its rather scanty bulk of foliage." Dr. Leonard Cockavne between 1919 and 1922 made an economic investigation of the montane tussock grassland of New Zealand. Initially Cockayne was characteristically sceptical of the opinions held by Armstrong, Buchanan, and Petrie on the value of New Zealand bluegrass, and his own opinion was summed up in the few words "may be palatable." Cockayne's final decision was, however, in favour of New Zealand bluegrass as a fodder plant of primary importance when in competition with species normally found in the tussock grasslands., In his book "The Vegetation of New Zealand," Cock-" ayne stresses the palatability for sheep of New Zealand bluegrass. Since Cockayne's time New Zealand bluegrass has been generally accepted as one of the more palatable native grass species and as a grass which has been more widely distributed than is at present indicated.

The invasion of the tussock grasslands by 


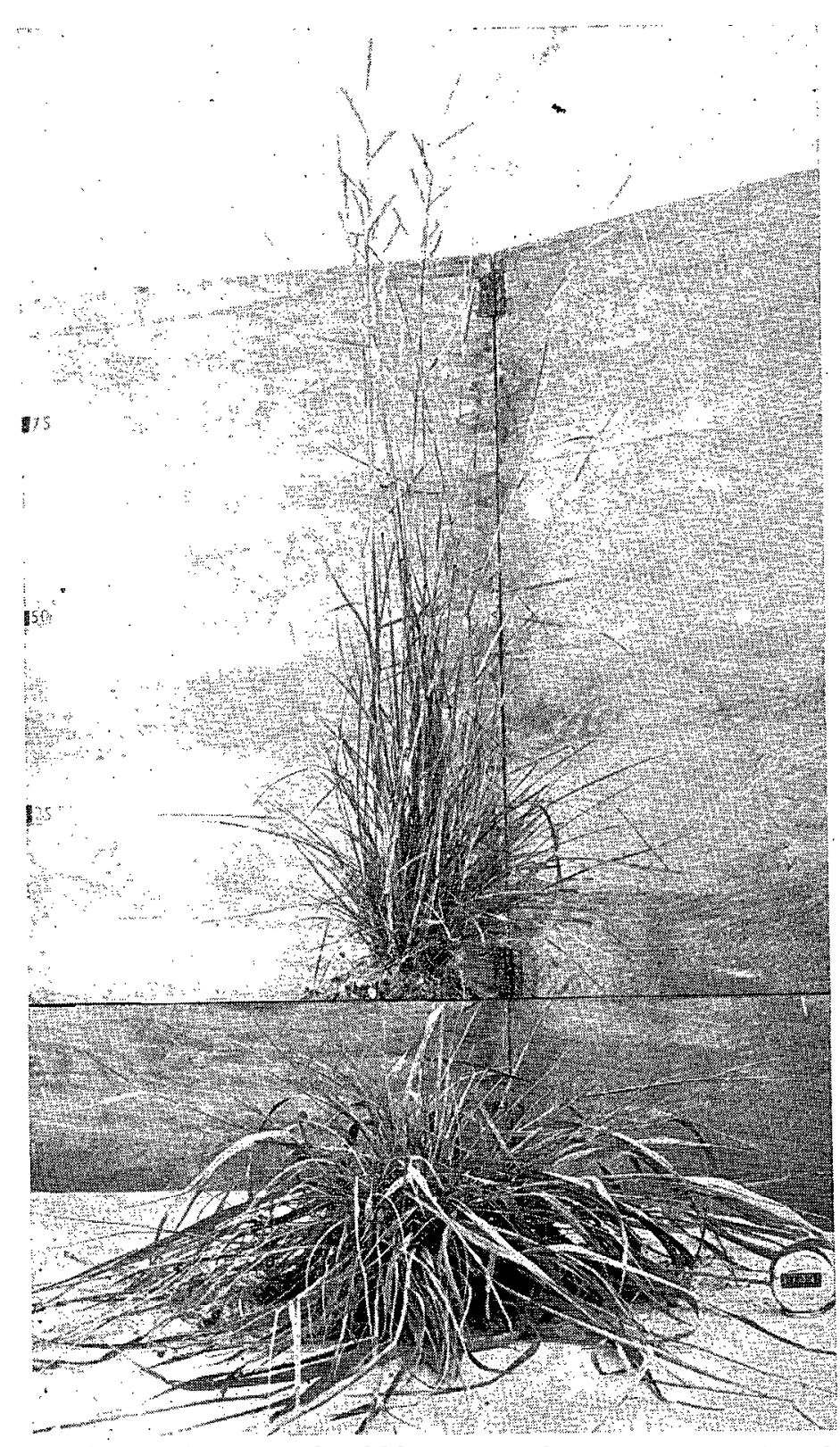

Two forms of New Zealand bluegrass. Above, erect type found in tussock grassland in low-rainfall areas; below, prostrate coastal form 
naturalized grasses, which it seems are there to stay, does affect the fodder value of New Zealand bluegrass, as it is then not in competition only with plants normally found in tussock-grasslands. Two of the most widespread aliens are Yorkshire fog and sweet vernal, and though Cockayne rates Yorkshire fog higher in palatability than sweet vernal and bluegrass, which he rates equal, today's opinion would, I think, be that both fog and sweet vernal provide more forage for sheep than does' New Zealand bluegrass. The qualitative question of palatability has partly given way to one of quantitative superiority.

New Zealand bluegrass was also chosen for study because it has a wide distribution throughout New Zealand and occurs in numerous habitats under divers soil and climatic conditions. But it was also chosen because-and this is a very important reason-it shows a very wide range of variation in the total species complex. The more widely variable the species the greater the range for selection of characters and the greater the chance of finding suitable types for special areas.

There is, of course, the possibility that an extremely variable population of some grass species could be introduced into New Zealand to be tested against New Zealand conditions. The sorting out by natural processes from this collection is possible, but of course very much the long-term project.

To answer briefly my second question, "How is the study of New Zealand bluegrass being made?" I wish to make it clear that the work is so far only in the experimental stages. From many differing areas collections of living plants and their seed have been taken to Wellington and grown at the Botany Division Experimental Area at Waiwhetu. These collections have been sorted out into groups of similar appearance and the morphological differences amongst them noted. So far about 15 distinct types, or groups as I call them, have been recognized, and I do not suggest that I have collected the lot. Each group has, as far as has been possible. been subjected to an examination of its distributional limits so that its natural areas may be readily defined. An attempt has been made to correlate these distributions with climatic and soil conditions. The breeding structure has been investigated and the species as a whole is considered selffertilising. All groups breed true. Experiments to determine the extent of natural crossing where mixed 
populations are found have also been conducted. Controlled crossing experiments to, show the natural relationships of groups has also been done among some groups. For the benefit of those interested in experimental taxonomy the present indications are that among the native species A. scabrum and A. kirkii form two ecospecies of one coenospecies ; A. enysii and A. scabrum var. tenue form two other separate coenospecies. All three coenospecies belong to one comparium of world-wide existence. Germination tests, reproductive capacities, incidence of plant diseases, strike and emergence trials, and method and form of tillering have been studied.

What of a practical, nature has been done to determine how the groups, of New Zealand bluegrass grow in the various tussock-grassland situations? So far five experimental row sowings have been made, one at Molesworth, one at Craigieburn, one at Earnscleugh, one at Mid-Dome, and one at Wither Hills Reserve. No other practical approach has yet been made, and as yet it is premature to make an estimate of the worth of any particular group or race.

I am of the opinion that important though the problem of introducing palatable species into the tussock grassland may be, more important still is the necessity to determine the ecological balance between palatable and protective species under natural conditions and grazing management and to produce and maintain this balance.

The natural conditions which pertain to the high country are not easily or readily adjustable and we must therefore make our plants fit our conditions. My thesis contends that the tussock grasslands have not been adequately tried out and thus cannot be condemned out of hand; their structure is climax and as such is suited in its natural areas. The problem is therefore not to create a new type of grassland for the high country, but to reproduce the type of grassland which Nature deemed fitted to these. areas.

There are in the tussock grasslands. of New Zealand plants which have fitted these conditions for hundreds of years and which have as yet hardly been explored, let alone exploited for purposes of rehabilitation.

The source of material for revegation is there, New Zealand bluegrass is only one of the potentials; the recognition of others can come only from 'the efforts of those whose work is grassland farming. 